Vol. 2, nº 1 | 1998

Varia

\title{
The Politics of the Rising Crime Statistics of England and Wales, 1914-1960
}

The Herman Diederiks Prize Essay for 1997 / Lauréat du Prix Herman Diederiks 1997

Howard Taylor

\section{(2) OpenEdition} Journals

Electronic version

URL: https://journals.openedition.org/chs/989

DOI: $10.4000 /$ chs. 989

ISSN: 1663-4837

\section{Publisher}

Librairie Droz

\section{Printed version}

Date of publication: 1 January 1998

Number of pages: 5-28

ISBN: 2-600-00279-0

ISSN: 1422-0857

Electronic reference

Howard Taylor, "The Politics of the Rising Crime Statistics of England and Wales, 1914-1960", Crime, Histoire \& Sociétés / Crime, History \& Societies [Online], Vol. 2, nº | 1998, Online since 03 April 2009, connection on 22 March 2022. URL: http://journals.openedition.org/chs/989 ; DOI: https://doi.org/ $10.4000 /$ chs.989 


\title{
The Herman Diederiks Prize Essay for 1997 Lauréat du Prix Herman Diederiks 1997
}

\section{The Politics of the Rising Crime Statistics of England and Wales, 1914-1960}

\author{
Howard Taylor ${ }^{1}$
}

This article argues that between 1914 and 1960, the criminal statistics of
England and Wales reflected supply-side politics rather than the amount of crime in the "real» world. After the police went on strike in 1918 their wages were increased. This led to central and local pressure to cut police numbers. Under the leadership of Sir Leonard Dunning, provincial police forces started to fight back by raising their crime statistics in order to move crime control up the political ladder. In 1930 the government accepted that crime figures would continue to rise and the Metropolitan Police, which was under Home Office control, quintupled its crime rate in three years to bring it into line with the provincial forces. The result was that in the post-Second World War period, crime control began to assume greater political salience than alternative programmes of social welfare.

Cet article soutient qu'entre 1914 et 1960, la statistique criminelle de l'Angleterre et du Pays de Galles refléta une "politique de l'offre» plutôt que l'importance de la criminalité dans la "réalité». Après la grève de la police de 1918, les salaires furent augmentés, ce qui suscita des pressions au niveau national et local en vue de réduire les effectifs. Sous la direction de Sir Leonard Dunning, les forces de police régionales ripostèrent en faisant augmenter leurs statistiques pour donner un poids politique plus important à la question de la criminalité. En 1930, le gouvernement admit que la statistique criminelle continuerait d'augmenter et la Metropolitan Police, qui était sous l'autorité du Home Office, quintupla son taux de criminalité en trois ans pour l'amener au niveau de celui des polices provinciales. Le résultat fut que, dans l'après-Seconde Guerre mondiale, la lutte contre la criminalité acquit une visibilité politique supérieure à celle des programmes sociaux alternatifs.

Well before the First World War, there had developed at the Home Office, as Radzinowicz and Hood put it, a « very optimistic approach towards crime and its control $»^{2}$. The international prestige and reputation of the Home Office derived

1 The author completed his doctoral thesis on the politics of crime in inter-war England and Wales in 1997. Two other articles by the author will be published later this year: Rationing crime: a political explanation for the constancy of criminal statistics in the Victorian period and later in the Economic History Review and The politics of policing the motorist in preference to the drunk in inter-war England and Wales in the British Journal of Criminology. He is currently researching judicial practices in the nineteenth and twentieth centuries and has been elected to a Research Fellowship at Gonville and Caius College, Cambridge from October 1998. (c) Librairie Droz.

2 Radzinowicz, Hood (1990, p. 778). 
from its manifest control of crime as shown in the Judicial Statistics, which, by the outbreak of the First World War had been kept stationary for well over half a century and were even decreasing, relative to population growth ${ }^{3}$. The international opinion was that «England was freeing itself from its crime, a dream entertained in vain by so many European countries ${ }^{4}$.

The sporting image of British justice (and for the indigenous colonial population this largely meant criminal law) also gave legitimacy to British governance in the Empire. Particularly in India, which was in perpetual crisis, the government wanted to avoid supplying colonial independence movements with explosive evidence which suggested that the British people found their own institutions anything other than perfect ${ }^{5}$. Instead, it wished to inspire the Empire to emulate the image of the British people as the most orderly nation on earth, and submit gratefully to her benign rule as the moral policeman of the world.

On the domestic front, since at least the 1880 s, the salience of crime had been declining as a discrete social problem, encouraged by the statistics. By the early twentieth century, crime was widely seen as one of the lesser symptoms of a recently discovered general degeneration «in the quality of the nation, the fitness of the race and the efficiency of the Empire ${ }^{6}$. The solution to crime, therefore, was believed to lie less in prisons than in the general improvement of the social and physical condition of the nation and, in particular, of the rapidly multiplying residuum who had been left behind by social progress. Consequently, social policy began «setting its course in a new direction away from deterrence and moralization $»$ which had traditionally characterized criminal policy. In its place, general programmes of social security, education, and eugenics were advocated to ameliorate real want, to prune and reinvigorate the stock, and to tutor the inefficient classes into more acceptable ways of living. Across the political spectrum, a progressive agenda developed where social progress, often advertised as a gratuitous by-product of capitalism or socialism, came to be seen as a more important weapon than the police in the defence of society against crime and degeneration ${ }^{8}$.

Contrasted with the wide-scale schemes of social reform coming on stream, criminal justice appeared old-fashioned and ineffective. It was small-scale, rule-bound and obsessed with petty details - the circumstances surrounding a particular crime and the individuals involved. The modern professional flag-ship programmes of social reform, such as education, medicine and housing, appeared more efficient. They claimed to tackle and even to eradicate crime in the abstract and in the mass, as a by-product of increasing national efficiency ${ }^{9}$. Since state funds were finite, this inevitably led to competition for funding between social reform programmes and criminal justice. As early as the 1860 s, Mr E.C. Tufnell, one of her Majesty's Inspectors of Schools, promised that « if schools were universal... in 10 years' time we

3 Taylor (forthcoming).

4 Radzinowicz, Hood (1990, p. 125).

5 For the importance of the police in India see Anderson, Killingray (1992, ch. 3).

6 Garland (1985, p. 131); Searle (1971, p. 61); Wiener (1990).

7 Wiener (1990, p. 185).

8 For the origins of 'the Ameliorative Creed' see Radzinowicz, Hood, (1990, ch. 3). See also Wiener (1990).

9 Scotson (1994). 
should have approached to the annihilation of one-third of the criminal population... in 20 years we should... have gone far towards preventing two-thirds of the crimes committed in this country $»$. Education reformers eyed hungrily the $£ 2,000,000$ wasted on "repressive penal administration ${ }^{10}$. Short of promises possibly to reform a few prisoners, criminal justice, with its more modest aims, could not compete against such claims.

At the level of political ideology, criminal justice was also in retreat. Reformers who aimed for the 'social good' were issuing a fundamental challenge to the traditional notion of the state as an external 'Leviathan' that existed only to protect individual citizens from high levels of crime and disorder ${ }^{11}$. In 1851, it had not seemed at all eccentric for Herbert Spencer to argue, in Hobbesian fashion,

Nay, indeed, have we not seen that government is essentially immoral? Is it not
the offspring of evil, bearing about it all the marks of its parentage? Does it not
exist because crime exists? Is it not strong, or, as we say, despotic, when crime is
great? Is there not more liberty, that is, less government as crime diminishes?
And must not government cease when crime ceases, for lack of objects on which
to perform its function? ? $^{12}$

Sixty years later, the situation had been transformed. After involvement in measures of social welfare, government seemed more inclusive and no longer immoral or dependent for its legitimacy upon crime. It could shed its criminal justice responsibilities. A new situation had developed where expansive domestic and foreign policy were both justified (and partly funded) by the seeming development of lawabidingness among the British people and the accompanying low and declining rate of crime, as recorded in the Judicial Statistics. The statistics allowed Britain, at the turn of the century to imprison only 1 in 1,764 of her subjects, mostly on short sentences compared with America which imprisoned 1 in 759 for longer terms ${ }^{13}$.

In these circumstances, it was not surprising that Victor Bailey found that the Home Office was presenting an upbeat, progressivist and declining analysis of the crime problem at the end of the First World War ${ }^{14}$. Falling crime statistics were now used by the state as one of the key indicators of the effectiveness of social reform, and of government itself, and there was no political incentive to change this. So, as the state increasingly ceased to regard itself as a Leviathan, the institutions of criminal justice were allowed slowly to wither away ${ }^{15}$. It was left to civil servants to deal with the long run-down of criminal justice administratively, cheaply and invisibly, and to prevent it re-emerging to the public as a problem out of control requiring expensive and impossible political solutions ${ }^{16}$.

\footnotetext{
10 Papers submitted to the education committee by E. Chadwick (1862, pp. 48-49).

1 See, most notably, Hobbes (1950).

12 Spencer (1851, p. 207). For a more recent, and extreme, restatement of the case see Nozick (1980).

13 Judicial statistics P.P. (1901 [Cd. 705], LXXXIX.257, p. 19).

14 See also Bailey (1987).

15 For the withering of criminal justice see Taylor (forthcoming).

16 For a fuller discussion see Taylor (1997).
} 
When the First World War began, the number of 'Crimes Known to the Police', which was the 'headline' statistic used to measure the total amount of crime committed, fell very sharply until 1916 , and then rose only moderately after that ${ }^{17}$. Many police officers had left their forces to enter the military, and the fall in the figures was used to allow police forces «to reduce the purely preventive duties» and concentrate more fully on war work ${ }^{18}$. Some routine patrol work was taken over by private citizens who enrolled as voluntary Special Constables or Women Police. They apparently found that they could do much of the job adequately themselves. During 1916, the press contained many stories of how crime was diminishing, courts were emptying, and prisons were closing ${ }^{19}$. It was suggested that the decrease in crime « will not end when the war ends ». The principle reason for this optimism being the restriction of alcohol sales which the "experts» said had previously been directly responsible for a «terrible... proportion of the crime of the country ${ }^{20}$. Immediately after the War, therefore, crime was barely mentioned in the evidence given to the Desborough Committee on the police service (see below) or in the Commons' debate on the resulting Police Bill ${ }^{21}$.

To an extent, complacency about crime encouraged a feeling that the police had become redundant in its daily duties. More astute members of the service, such as Sir Leonard Dunning, an Inspector of Constabulary, saw the writing on the wall, and before the end of the War was fearing for the future funding of professional preventive policing:

it remains to be seen whether the altered circumstances of the country will call for an increase of police forces, or whether the resumption of the police duties by the citizens themselves during the period of the war has taught them to rely upon their own powers for the protection of themselves and their property instead of leaning on the police 22 .

Police funding and conditions had rapidly deteriorated during the War, and this had been aggravated because, for some years previous to the War, pay and promotion prospects had been allowed to decline leading to the development of police trade unionism immediately before the war $^{23}$. By 1918 police forces had became aged, «sickly " and discontented, and pay was eroded to a point where they were living close to the breadline ${ }^{24}$. Then in 1918 , and again in 1919, the police went on strike ${ }^{25}$.

17 Judicial statistics (1914-1918).

18 Inspectors of constabulary P.P. (1916 (35), XIV.605, p. 5); Emsley, (1991, p. 116).

19 Times Index (1916, 'Crime').

20 Times (6 March 1916, p. 3).

21 Second Reading of the Police Bill, Hansard (Commons), 5th ser., CXVIII, 18 July 1919, cols. 795 843.

${ }_{22}$ Inspectors of constabulary, P.P. (1919 (38), XXVII.671, p. 3).

23 Martin, Wilson (1969, p. 35); Judge (1994).

24 Critchley (1978, p. 190).

25 Reynolds, Judge (1968). 
In February 1919, the Home Secretary announced the appointment of the Desborough Committee to inquire into what had now become the political problem of police service conditions. Desborough's most urgent task was to remove the fear, encouraged by police trade unionism, and expressed by the head of the CID and the political Special Branch, of the police ever «joining forces with the leaders of strike movements ${ }^{26}$. By «raising the economic, and thus the social, status of the average policeman far above anything he had previously achieved $*$ to a semiprofessional status, it was hoped to buy the loyalty of the force ${ }^{27}$. Desborough awarded large pay rises and banned unions ${ }^{28}$. Sir Leonard Dunning warned; «It is possible that the increasing cost of the police service will call for economy in numbers ${ }^{29}$.

Under Desborough, the cost of policing was split equally between reluctant ratepayers and a reluctant Home Office. The cost of maintaining the police establishment, at the current level, trebled as a result of the Desborough award, from about $£ 7,000,000$ in 1914 to about $£ 20,000,000$ in $1920^{30}$. In addition to finding the cost of the Desborough award, many local authorities had still to introduce the large increases in police establishments to cover the requirements of the 1910 Police Weekly (Rest Day) Act $^{31}$. This Act, if fully implemented, threatened to raise costs by a further 20 percent without providing any additional increase in public protection. From both left and right, local authorities criticised the "grossly overpaid" postDesborough police and had no great wish to maintain either their numbers or budgets $^{32}$. Central Government was in its usual ungenerous mood and remained "unwilling to pay more than half the cost of the police»" ${ }^{33}$. In the opinion of an Assistant Secretary at the Home Office, «The Home Office finds it very difficult to get money for anything, and I think we have a sort of feeling that it is going to be very much harder... The police are always rather a luxury, and some localities can afford the luxury more than others ${ }^{34}$.

Throughout most of the inter-war and immediate post-war period, this attitude persisted. S.J. Stevenson has argued that there was no evidence that « an increase in police numbers was really a matter of overriding Home Office concern ». This was true. In 1929, A.L. Dixon, on behalf of the Police Department put it succinctly, «The number of Police required for the maintenance of order, or the suppression of disorder, is far fewer to-day ${ }^{35}$. It appeared that the police were going to need either to find some urgent new work, such as crime or traffic control, to justify their new

\footnotetext{
26 Thomson (1935, p. 300); Lopian (1986, pp. 8-14).

27 Martin, Wilson (1969, p. 36).

28 Judge (1968, p. 2).

29 Inspectors of constabulary, P.P. (1920 (91), XXII.463, p. 3).

30 Critchley (1978, p. 193).

3t Martin, Wilson (1969, p. 37); Critchley (1978, pp. 171 ff).

32 Judge (1994, p. 41).

33 Martin, Wilson (1969, p. 55).

34 Evidence of H.B. Simpson, Assistant Secretary, Home Office, Committee on the police service, (1920, pp. 9, 5).

35 Stevenson (1995, p. 63); Evidence of A.L. Dixon, Royal commission on police powers, (1929, p. 173).
} 
expensive semi-professional status or, as the Inspectors of Constabulary feared, expect calls for their numbers to be reduced ${ }^{36}$.

These calls were made repeatedly ${ }^{37}$, and for almost the entire inter-war period, police numbers and expenditure was subject to constraints and review, particularly during the economic crises of 1922 and 1931. By 1932, Sir Llewelyn Atcherley, an Inspector of Constabulary, was complaining that «we have been for so many years economising and economising that we have come almost to bedrock. We are even discussing wearing one pair of trousers instead of two ${ }^{38}$. In these circumstances, the police did extremely well to keep their manpower virtually stationary throughout the period, the actual strength of the police in England and Wales in 1921 was 59,520 , in 1935 it was 59,230 , and by the run-up to the Second World War 1939 it had reached 63,980 , but much of this increase was in anticipation of civil defence work ${ }^{39}$.

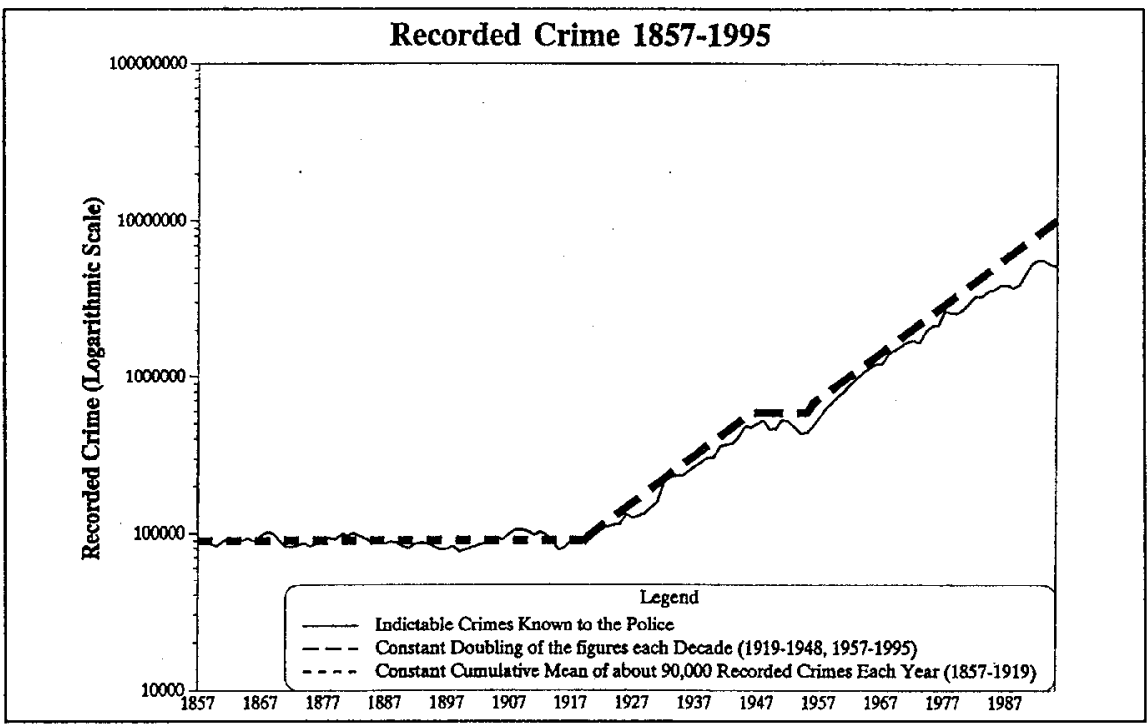

Figure 1

Suddenly, the situation transformed as crime began to move up the political agenda. The reason was that, in 1920 , crime indices, which had remained almost sta-

Inspectors of constabulary, P.P. (1920 (91), XXII.463, p. 3).

See, example the comment made by Sir Hugh Bell, a coal owner and magistrate, to the Monthly luncheon of the individualiste Bookshop; « he was willing to pay a reasonable amount and not the extravagant sums he had to pay now, when he did not get that regulation and order that he wanted and when he got a good deal he did not want.» The sort of regulation and order he wanted was that maintained in Sweden where police had threatened to fire on strikers. This meeting was attended by Edward Short who, as Home Secretary, had set up the Desborough Committee, Times (27 October 1927, p. 11).

38 Evidence of Sir Llewelyn Atcherley, Select committee on the amalgamation of police forces, (19312, p. 157).

39 Martin, Wilson (1969, p. 47). 
tic for decades started coming to life. Leading the figures upwards was the table of 'Indictable Offences Known to the Police'. In just two years this had reached an alltime high of 107,000 crimes). From then on, with remarkable consistency until the late 1970s, with the exception of a brief interlude in the 1950s, this figure almost doubled every decade.

II.

In his report for 1920-1, Sir Leonard Dunning, the senior Inspector of Constabulary had asked; "Can anything be done by central criticism and instruction to give this figure of Crimes Known to the Police the value which it ought to possess? It does not seem likely that many crimes are wrongly included, but the exclusion of crimes which ought to appear is beyond doubt $\gg{ }^{40}$.

As the senior Inspector of Constabulary ${ }^{41}$ when the war ended, Sir Leonard Dunning was well placed and highly motivated to raise the standards of policing and protect its resources. Although he has received little attention in the historiography, he was one of the leading police officers of the late nineteenth and early twentieth century who were effecting « a shift in the balance of police work away from the preservation of public order towards the prevention and detection of individual crimes ${ }^{42}$. Although prevention had always been a primary duty of the police, Dunning took the concept further than other leading police figures by seeking to recreate parts of the duties of the uniformed police almost as a branch of social service. Before the end of the First World War, Dunning had already felt that the official statistics greatly understated the extent of crime and, in particular, that the figures did not show how much crime was rising. After he was appointed Inspector of Constabulary in 1912 he wrote; « if the returns... did really show all the cases which ought to be included, there would be on paper an increase of crime, which by its obvious exaggeration would draw attention away from the real increase, consistent and progressive for some years past ${ }^{43}$.

Before the First World War, Dunning had been the Head Constable of Liverpool. His predecessor, Sir William Nott-Bower, later admitted, «It is impossible to compare Liverpool (as has been attempted) with other towns by quoting statistics $»^{44}$. Liverpool's figures were much higher than anywhere else and they were used to justify the highest police man-power levels per acre, and per head of population outside London ${ }^{45}$. In the 1890's, the Home Office began to impose uniformity, and Sir William brought Liverpool in line with other cities. By the time he left, he had brought Liverpool's crime 'co-efficient' sharply down to exactly the rate of 611 crimes per 100,000, that the Home Office expected from a 'normal' for a seaport ${ }^{46}$.

40 Inspectors of constabulary, P.P. (1922 (5), X.303, p. 11).

41 The body officially responsible for inspecting and maintaining the efficiency of all police forces, apart from the Metropolitan Police.

42 Martin, Wilson (1969, p. 11). For the reluctance of police to detect and prosecute indictable crime in the nineteenth-century see Taylor (forthcoming).

43 Inspectors of constabulary, P.P. (1914 (193), LXVII.663, p. 57).

44 Nott-Bower (1926, p. 142).

45 Ibid. (p. 69).

46 In 1898 the Judicial statistics provided a table of the normal crime rates for different types of districts. Seaports, such as Liverpool, nomally had the highest crime rates averaging 611.10 indictable 
He also made an « unparalleled» 75 percent cut in Liverpool's enormous figures for drink prosecutions and brought about a very large decline in prosecutions for offences against the person ${ }^{47}$. In 1902, Nott-Bower left to take up the chief constableship of the City of London and Dunning, his deputy, was appointed the new Head Constable.

Reviewing Dunning's first years as Head Constable, Francis Caldwell, the Head of CID, revealed, «the offence work has increased very much in the last five years and is still on the increase ${ }^{48}$. On 1 June 1903, Dunning introduced a new system of recording crime and, by the end of 1905 , the city's crime rate had doubled compared with $1902^{49}$. Dunning's stated aim was to make his figures «further reaching and more reliable " ${ }^{50}$. As a result, Liverpool had, by a great margin, the highest crime rate in England and Wales. With 1,222 crimes per 100,000, she had three times Birmingham's rate of 416 , over four times London's rate of 300 , and nearly five times Leeds' rate of 263. The average for England and Wales was only $277^{51}$. What was not commented upon was that Dunning had exactly doubled the Liverpool crime rate. Immediately upon his appointment, Dunning began to push the crime rate to an all-time high of 1221.68 per 100,0000 , an increase of 99.81 percent in three years. This was clearly a planned, bookkeeping increase, since there was no increase in persons apprehended for indictable offences ${ }^{52}$. Dunning's attitude was, as he later admitted in 1919, «Now, of crimes known to the police, the figure is one on which to place very little reliance, because it is what I call a discretionary statistic; the man who has to prepare that figure can put down pretty much what he likes ${ }^{53}$.

Dunning received a mild rebuke and check in the Judicial Statistics of 1905; «much stress ought not to be laid upon this increase». It went on to warn that Dunning's action had cast doubt upon the integrity of the statistics as a whole. His figures were «exceedingly high... They raise doubts whether all the figures here stated have been collected in the same manner ${ }^{54}$. Nonetheless, Liverpool's figures continued to rise, from 4,234 in 1902 to 14,041 in 1910 - an increase of over 16 per cent per annum. In these eight years, Dunning had raised Liverpool's share of 'Indictable Crimes Known to the Police' from 5 per cent to 13 percent of the total for England and Wales, although the City still only employed about 3 per cent of the total police force.

The reason Dunning had raised the figures was because he had a clear vision of how he would like professional policing to develop that involved increased numbers and duties. He wanted to follow up crimes even when they were unlikely to lead to prosecutions:

crimes per 100,000, Judicial statistics, P.P. (1900 [Cd. 123], CIII.1, p. 31). By 1902, when Nott-Bower left, Liverpool's rate was 'normal' at 611.41.

47 Judicial statistics, P.P. (1901 [Cd. 705], LXXXIX.257, p. 73).

48 Inspectors of constabulary, P.P. (1907 (128), XXXI.1, p. 97).

49. In England and Wales as a whole it rose about $10 \%$.

so Judicial statistics, P.P. (1907 [Cd. 3315], XCVIII.1, p. 66).

51 Ibid. (p. 62).

52 Ibid. (p. 66).

53 Evidence of Sir Leonard Dunning, Committee on the police service, (1920, p. 82).

s4 Judicial statistics, P.P. (1907 [Cd. 3315], XCVIII.1, p. 66). 
if the older attitude provided excuses for slackness, the newer attitude must stimulate action. In old times a crime by a child, if not thought worth a prosecution was in too many places not followed up... but prevention of crime is the first duty of the police, and anything which tends, however remotely, to the prevention of crime is their work; after all, the boy saved from crime and the girl saved from infamy are the gains, moral and material, of the community, whether the saving be done by the parson or by the police ${ }^{55}$.

III.

In the immediate post-Desborough period, Dunning exercised great influence over policing policy. In 1912 he was appointed the junior Inspector of Constabulary, in 1918, he became the senior Inspector. The second Inspector during the immediate post-Desborough years, Sir Llewelyn Atcherley, was not appointed until 1919, long after Dunning. At the time he gave evidence to the Desborough Committee, Atcherley had only been at the Home Office for «a few weeks $»^{56}$. So, although he was an innovator and had long enjoyed great status and prestige in the police service, Atcherley's appointment came too late to exert a decisive influence in the formative period, immediately during and after Desborough, when police establishments were under particular scrutiny and strategies were urgently needed to safeguard police numbers from the anticipated calls for economy. Moreover, Atcherley's expertise and interest lay in the development, as recommended by Desborough, of co-operative arrangements between police forces and in the establishment of crime clearinghouses of which he was a pioneer ${ }^{57}$.

The Home Office had no other expert to rival Dunning. Until Desborough focused the Home Office's attention on routine policing duties, the Department had had, as Edward Troup, the Permanent Under-Secretary revealed in 1925, "little to do with the ordinary executive duties of County and Borough Police - the suppression of crime, the arrest and prosecution of offenders ${ }^{58}$. In the view of Sir Leonard Dunning; His Majesty's Government, «has information about the experience of the Metropolitan Police alone, it knows little of what the other 186 police forces in England and Wales are doing, the developments in police methods initiated by them and the work which they do which the Metropolitan Police does not do ${ }^{59}$.

So far as the statistics were concerned, this had not mattered to the Home Office in the past, since the Inspectors generally maintained the status quo, equating low rates of crime with efficiency ${ }^{60}$. Dunning had a very different philosophy. As the Reports of the Inspectors of Constabulary show, he identified low crime rates as a sign of police inaction and urged forces to put up their figures ${ }^{61}$. Chief constables

55. Evidence of Sir Leonard Dunning, Departmental committee on the duties of women police, (1921, p. 11).

56 Evidence of Sir Llewelyn Atcherley, Committee on the police service (1920, p. 337).

57 Inspectors of constabulary, P.P. (1914 (193), LXVII.663, pp. 3-4); Critchley (1978, pp. 193 ff.); Dixon (1936).

58 Troup (1925, p. 103).

59 Evidence of Sir Leonard Dunning, Committee on the police service (1920, p. 86).

60 See, for example, Inspectors of constabulary, P.P. (1861 (67), LII.641, p. 9).

61 Evidence of Sir Leonard Dunning, Departmental committee on the duties of women police (1921, p. 12); Inspectors of constabulary, P.P. (1922 (5), X.303, p. 12). 
could respond because Desborough had deliberately increased their political autonomy from their police authorities ${ }^{62}$ who wanted to keep crime levels low.

The main Home Office official who was in a position to challenge Dunning was Arthur Dixon, the Secretary to the Desborough Committee who, during the War, had taken charge of an embryonic Home Office Police Department, but its main concern had not been with crime, but with the policing of the Defence of the Realm $\mathrm{Act}^{63}$. The Police Department of the Home Office was not formed until 1922, as a result of a Desborough recommendation, so in the crucial years of 1919 and 1920, Dixon still lacked the status, organization, knowledge, and experience to exert a counterinfluence over such a senior voice in policing circles as Dunning. At that time, Dixon was still on a learning curve, over-burdened with Desborough work and, according to the President of the Chief Constable's Association, he «did not then know much about the inner workings of the Service.. I heard it said: 'Mr Dixon at the Home Office is eating up everything appertaining to the Police' ${ }^{64}$.

So, initially, until Dixon and Atcherley could establish themselves, Dunning was in a very powerful position to preach a vision of large-scale, large-establishment preventive policing as the model for a new, post-Desborough professional police force ${ }^{65}$. His evidence to the Desborough Committee, and the fact that he was twice recalled, confirm he had become the leading voice of police professionalism in the country and, largely owing to the vacuum of disinterest at the Home Office, he was the only witness to the Committee who displayed a clear conception of the direction a professional force might take at this critical juncture in police history ${ }^{66}$. When, shortly after Desborough, plans to cut police establishments were revealed, Dunning's unsurprising reply was that he was «mainly concerned in attaining a result opposite to the reduction that is now being sought $»^{67}$.

\section{IV.}

In 1921, the publication of the preliminary report of the Census led police authorities to discuss in earnest whether so many police were necessary per head of population ${ }^{68}$. The following year, the first large attack on the police establishment came with the Geddes Axe on Public Expenditure which required a 5 percent saving in police numbers. This amounted to a cut of 1,000 uniformed beat officers from the Metropolitan Police alone ${ }^{69}$. Neither Geddes nor many police authorities believed that the existing numbers of police were still justified. In order « that the numbers of Police will be adequately reduced $»$ the report suggested,

\footnotetext{
62 Weinberger (1991, p. 213).

63 Inspectors of constabulary, P.P. (1919 (38), XXVII.671, p. 4).

64 Vote of thanks to Arthur Dixon by Chief Constable R. Ogle. Dixon (1936, pp. 59-60).

65 He continued to remain highly active after the Police Department was set up in 1922, Morgan (1987, p. 11).

66 Evidence of Sir Leonard Dunning, Committee on the police service, (1920, pp. $82 \mathrm{ff} ., 110 \mathrm{ff}$.).

67 Inspectors of constabulary, P.P. (1922 (5), X.303, p. 4).

68 Ibid. (p. 4).

69 Commissioner of the metropolitan police, P.P. (1922 [Cmd. 1904], XII Pt. 2.313, p. 1).
} 
a full investigation should now be made as to the strength of all Police Forces, beginning with those whose present establishment appears to be on a more generous scale than the average, and that the Home Office should at once endeavour to arrive at a basis of the numbers required for the adequate policing of each area. We think that such a basis, calculated upon acreage, population and ratable value, should be introduced with the least possible delay ${ }^{0}$.

Forces were well aware that they had no influence over the variables of acreage, population, or rateable value. Police forces did however, have control over that « discretionary statistic " of the amount of indictable crime recorded ${ }^{71}$ and, as S.J. Stevenson has observed, they used it to persuade police authorities to endorse calls from the forces for increases:

Long-term increases in reported crime made all Chief Constables, Borough Watch Committees, and Standing Joint Committees in the counties exceedingly anxious to retain or increase numbers of local police in any urban centre, and always the trend was now to justify new requests not in terms of police per head of population but rather in terms of police available relative to steady increases in reported crime ${ }^{72}$.

Writing in 1932, James Clayton, the Chief Constable of Doncaster, a representative of the Chief Constables' Association, and who had served at every rank in the service, was quite clear that «the increase in the number of crimes is more apparent than real » and that the decision to record crimes of a «nominal» value, such as «the stealing of a bottle of milk from a doorstep », originated in the «book-keeping » decisions of a number of chief constables ${ }^{73}$. The obvious conclusion is that these senior police officers had played the crime card to undermine Geddes and, by extension, government policy with the hope of, at least, maintaining, if not improving their establishments. Consequently, Geddes was informed, by Dunning, through the medium of the Reports of the Inspectors of Constabulary, that the level of crime had to be taken into account when deciding police strengths; «if anybody proposes to occupy his time in searching for this formula, which has still to be found, there is another figure which he should most certainly include in his calculations... the "crime-coefficient' of the police district ${ }^{74}$. In a classic version of an argument that had been heard before and was to be rehearsed many times over the next seven decades, Dunning continued; «One may at once say that the reliability of these figures has improved very much of late years and that they now come nearer to a correct representation of facts than they did in years gone by... [this figure is] one reason why vacancies should be filled and, in some cases why establishments should be increased ${ }^{75}$.

70 Committee on national expenditure (1922, p. 58).

7 During the early twentieth century, Chief Constables had been taking over the production of the criminal statistics from the magistrates clerks who often had previously compiled them. By 1930, the large majority of statistical returns were under the control of Chief Constables. MacGregor (1953, p. 39).

72 Stevenson $(1995$, p. 62).

73 Memorandum submitted by James Clayton DCM MM, Select committee on the amalgamation of police forces, (1931-1932, p. 229).

74 Inspectors of constabulary, P.P. (19245 [Cmd. 2316], XV.177, p. 9).

75

Ibid. 
When discussing drink convictions in his 1920-1 Report, Dunning likened the selection process to a machine for grading road metal, where the grades of stone used could be changed. To increase its convictions, a police force merely needed to increase the gauge of the holes in the machine. He was arguing that crime statistics could be made to appear to rise when the statistical base changed from year to year; "In this simile of the machine, one must remember that it is not one machine of known and stable gauge which might be expected to give stable results, but that the 180 odd police forces represent so many machines of which no two were originally of uniform gauge or are kept to gauge from year to year ${ }^{76}$. So, to increase the crime figures, Dunning merely had to persuade a number of forces to keep increasing the gauges they used to record indictable crime.

Since property offences were the main concern of the police, the gauge most forces used was the monetary value of the goods stolen. In all forces there was a vast reservoir of unrecorded crime since large numbers of smaller property offences

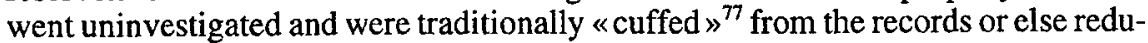
ced to non-indictable charges. Dunning encouraged chief constables to record more of this minor crime. He provided chief constables with arguments to persuade their police authorities that some of this should really be treated as serious crime requiring augmentations to their establishments:

the test of mere money value, which is generally accepted, is fallacious. To justify one's saying that a crime is serious or not, one must know how it affects not only the person who suffers by it, but also the person who commits it. The theft of five shillings may not seem serious, but would be so if the five shillings stood between the loser and actual want, and it must be remembered that the poor, to whom five shillings may mean much, suffer more from crime than the rich... Again, if the theft were the first success which started a child on a life of crime, it would be serious... Again, such a theft if the work of an old hand with not the smallest intention of reform, would not be serious so far as he was concemed, it would only add another spot to the leopard's skin. The word «serious» will inevitably be used in any discussion on the sufficiency of a police force for dealing with crime ${ }^{78}$.

Traditionally, those who reported crimes to the police were often met with open disbelief and, unless they were obviously respectable, could face a mini third degree to establish their status, credibility and whether they had sufficient finances to prosecute, before the police would accept the crime and start an investigation. In the 1930s, standard police works were still advising officers that «The class of person involved should be recorded by the investigating officer » and that he should obtain such information as: What is his «financial status »? «Is the complainant genuine»? Does the complainant have delusions ? $^{79}$. However, by the early 1930 s, the author of these questions, Major-General Llewelyn Atcherley, Dunning's fellow Inspector of Constabulary, had noted, «the disposition now is to more often register a doubtful

${ }^{76}$ Inspectors of constabulary, P.P. (1922 (5), X.303, p. 13).

$\pi$ British police jargon for not entered as a recordable crime.

78 Inspectors of constabulary, P.P. (1924 (19), XII.65, p. 9).

79 Atcherley, Brook (1932, p. 63). 
instance as crime - in the absence of positive proof one way or another - rather than to exclude it for the same reasons $"{ }^{80}$.

Before the War, to keep crime figures down, most reports of theft were entered into a Suspected Stolen Book, rather than into the Crime Book, «unless subsequent evidence or the conviction of the person by a Court removed any further possibility of doubt ${ }^{81}$. This kept the figures down, the clear-up rate high, and cut down on police work, since this placed the onus on the injured party to prove that a crime had been committed, rather than on the police to investigate whether or not this was the case.

The abolition of the Suspected Stolen Book was an easy way to raise crime figures at a stroke. From the 1920 s, many of the sudden permanent leaps in crime that appeared in the local statistics, can most probably be explained by Suspected Stolen Books being abolished, either within a division, or within an entire force. Otherwise, more gentle and constant increases could be obtained by changing practices in the classification of offences. Offences could be classified in any number of ways depending on the orders given to charge officers and the way the elements of the offence were interpreted. So, a charge officer could reduce an offence to make it non-indictable, or increase it to an indictable crime. To raise a force's figures, it was only necessary to set the charge officer a target to increase indictable crimes by a certain percentage. Since vastly more offences were classified as non-indictable or suspected crime than were recorded as indictable, police forces had an enormous reservoir of what had been traditionally dismissed as minor offences that could at any time be promoted to make a serious indictable crime.

Consequently, the great rise in house and shop breakings, that were a notable and alarming feature of the inter-war period, probably largely resulted from changes in classification of small offences. There were earlier precedents. In London, in 1878, following the formation of the CID the previous year, burglaries and housebreakings suddenly rose 330 percent due to a change of classification from «larcenies or kindred offences 》. The Judicial statistics noted in 1899:

Crimes which at one time and in one district are classified as burglary will at another time and elsewhere be classified as larceny, and conversely. Thus, opening premises by means of skeleton keys or lifting a window already half open or pushing back a catch of a window might be variously described in different returns. An apparent increase of burglary and housebreaking has sometimes been really ascribable to a sudden application of strict legal definitions ${ }^{82}$.

This was what Dunning meant in his frequent calls for a «more uniform administration of the law ${ }^{83}$. Uniformity in applying legal definitions would mean that

80 Inspectors of constabulary, P.P. (1931-2 (36), XII.639, p. 6). This statement was not true. Vast amounts of crime still continues to be 'cuffed', Young (1991, pp. $323 \mathrm{ff}$ ). From the vantage point of the 1980 s, a senior officer «described the period between the wars as equivalent to a 'golden age' of cuffing", Bottomley, Coleman (1981, p. 22). From the vantage point of the inter-war period, the nineteenth century would have appeared as the 'golden age'.

81 Commissioner of the police of the metropolis, P.P. (1932-3 [Cmd 4294], XV.319, p. 16).

82 Judicial statistics, P.P. (1901 [Cd. 705], LXXXIX.257, p. 22).

83 See, for example, his comments, Inspectors of constabulary, P.P. (1919 (38), XXVII.671, p. 4); P.P. (1922 (5), X.303, p. 10). 
small thefts would have to be classed everywhere as serious housebreakings or shopbreakings, placing pressure on authorities to increase police numbers.

\section{VI.}

There still remained one obstacle in the way of chief constables raising their crime figures. Most police authorities would not fund an increase in prosecutions and this would leave chief constables looking inefficient. As figure 2 shows, the total number of indictable prosecutions did not begin to rise until a decade after the police figures began to rise. Dunning had an answer. A decision in the new Court of Criminal Appeal in R. v. Syres (1908), allowed other offences admitted by a prisoner to be taken into consideration by the courts ${ }^{84}$. As a result, the Home Office added a new column to the Judicial statistics in 1910 and expanded it, in 1912, to include other cases of 'Crimes of which the perpetrators were detected but for which no proceedings are shown ${ }^{\prime 85}$. In his report for 1920-1, Sir Leonard argued how a chief constable could use this column to break the traditional link between prosecutions and crimes known to the police:

a certain Chief Constable, who, when his Crime Book was under inspection, expatiated on the difficulties caused to the police by persons refusing to prosecute, instancing a case in which an employer had complained to the police of thefts of raw material and then refused to prosecute an employee red-handed. Asked to show the case in his Crime Book he explained its absence: 'Why should I show a crime committed without any chance of showing a prisoner against it?' Though it is seldom so frankly admitted, it is understood to be the rule in some places to exclude from the return any case in which the injured person refuses to apply for process. Of late years a column has been added to the returns for showing the cases in which, though the perpetrators have been detected, there has been no prosecution, but the Chief Constable in question does not seem to have grasped this as an opportunity for preserving, even of improving, his cherished percentage $^{86}$.

Until the end of the First World War this figure remained at around 6,000 to 7,000 crimes a year or somewhat below 7 percent of the total number of crimes known. By 1922, the figure of crimes detected but not prosecuted, had risen to 13 percent of the total. By the late 1920 s, as the crime figures rose, it was approaching 25 percent of crimes of known to the police ${ }^{87}$ and had absorbed much of the increased crime.

\footnotetext{
Mannheim (1940, p. 44).

Ibid. (p. 39).

Inspectors of constabulary, P.P. (1922 (5), X.303, p. 12).

87 Calculated from Mannheim (1940, p. 42); see also Judicial statistics, P.P. (1929-30 [Cmd. 3581], XXX.395, p. XXXi).
} 


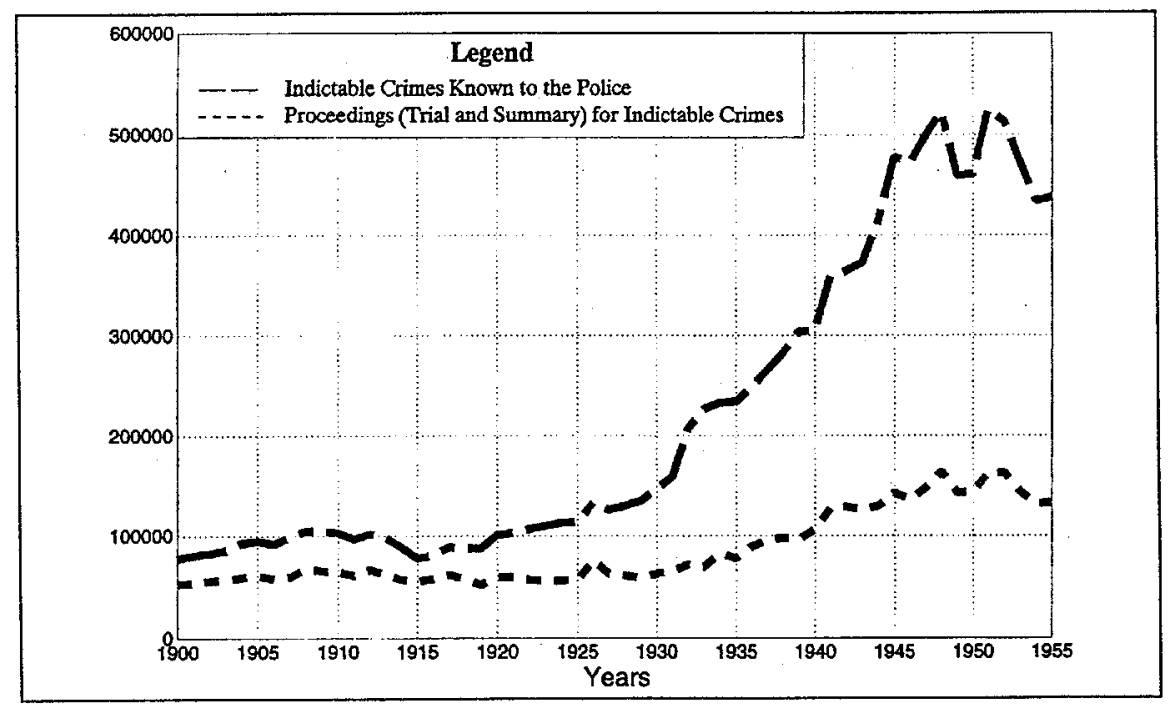

Figure 2

VII.

The sudden inflation of the police figures seems to have taken the Home Office by surprise. Evidence of this is that the Metropolitan Police, the only force which remained directly under Home Office control and also not subject to the influence of the Inspectors of Constabulary, continued to follow pre-war practices by recording a more or less constant level of between 15,000 and 17,000 indictable crimes in the decade 1919-298. Throughout the rest of England and Wales crime rose about 65 percent in this period ${ }^{89}$.

Until at least the mid-1920s, the Home Office stone-walled over the police figures. As an institution, it had at stake its prestige and reputation which depended upon its manifest control of crime. Moreover, the implication of rising crime was increased expenditure. It advised the public and politicians, to discount the increased police reporting of indictable offences as mere statistics and reassured them that crime «shows a definite tendency to further diminution $»^{90}$. Most police authorities had no more reason to want rising crime than the Home Office. They wanted their district's reputation to be kept clean from crime. Politically, there were calls for economy during the inter-war depression and all authorities had many other pressing spending priorities to meet.

88 Moylan (1929, p. 175); Commissioner of the police of the metropolis.

89 Judicial statistics.

90 Judicial statistics, P.P. (1924-5 [Cmd. 2385], XXVIII.63, p. 5). Compare this with the similar reluctance of the Ministry Health to acknowledge statistics of increasing malnutrition; Webster (1982, p. 123). 
The Home Office at first insisted that the police figures were unreliable, and that the almost constant number of prosecutions undertaken each year should be accepted as the measure of crime, as it had been in the nineteenth century ${ }^{91}$. These were supported by the Prison Statistics which similarly supported the traditional Home Office policy of falling crime. So, the 1922 Judicial statistics argued:

The figures of persons for trial for indictable offences are usually regarded as the most trustworthy index of the state of crime. Generally, the conclusions drawn from these figures are confirmed by those suggested by the figures relating to crimes known to the police. Latterly, however, the last mentioned figures have increased, while the number of persons for trial has become stationary or has even diminished ${ }^{92}$.

The police, therefore, had to expect powerful opposition before their figures were officially accepted as the best index of the real state of crime. Dunning fought strongly, in his Desborough evidence he had expressed the view that the small number of trials was no indication of the amount of crime. Instead prosecutions needed to rise :

where the police authority avoids every possible expenditure of money, the police often have to do the same as the injured person - nothing. Central control might help here - especially in the direction of assigning the cost. But the control would have to be very different from that now exercised by the Director of Public Prosecutions. If all prosecutions which seem to be advisable in the public interest were undertaken by the Director of Public Prosecutions, or if all police authorities acted alike in authorising the police to undertake them, a great deal more protection would be given to property ${ }^{93}$.

He also argued that the other figures had not risen for the simple reason that the police were being kept short of men and so could not catch criminals :

It may be safely assumed that a reduction of the police will lead to a reduction possibly of the Assize Calendar figures, certainly of those accepted by the Prison Commissioners, because without doubt the fewer the police the fewer will be the people brought to trial $^{94}$.

He skilfully disputed the Home Office's argument that education had reduced crime. Instead, he argued, "Though crime against the person is decreasing, crime against property, the crime of civilization, is increasing ${ }^{95}$. He also doubted that crime had been diminished by drink legislation since the War. He warned the Home Office could draw no conclusions from statistics of falling drink prosecutions; « the convictions for drunkenness bear no known or stable relation to the amount of drunkenness nor provide any measure of the result of legislative or administrative changes ${ }^{96}$. Over the next few years, Dunning tried to position the police among the

Radzinowicz, Hood (1990, p. 105); Radzinowicz, (1945).

Judicial statistics, P.P. (1924 [Cmd. 2265], XXV.719, p. 6).

Evidence of Sir Leonard Dunning, Committee on the police service, (1920, p. 86).

Inspectors of constabulary, P.P. (1924 (19), XII.65, p. 9).

Inspectors of constabulary, P.P. (1914 (193), LXVII.663, p. 57).

\% Inspectors of constabulary, P.P. (1922 (5), X.303, p. 13). 
expanding medical and social services which claimed to be preventing and curing crime, rather than among the courts and penal institutions who dealt only with failures. In this vein, he attacked Home Office reliance on the figures of the courts rather than taking into account wider effects of police work; «it is like measuring the fluctuations of some disease by the number of deaths only instead of by the total number of patients $"{ }^{97}$.

Dunning insisted that crime really was rising «by leaps and bounds » to record levels ${ }^{98}$. The Home Office continued to deny this, maintaining «The proportions that the indictable offences known to the police have borne to every 100,000 of the estimated population are far safer guides » and concluding « the crime rate has fallen greatly since $1857 » 99$. Slowly, the ground shifted in favour of the police as their figures rose higher and higher and Home Office explanations began to sound more and more complacent and far-fetched. In 1923, the number of court proceedings were still accepted by the Home Office as the leading index, although it was now admitted that the police figures «are, however, more trustworthy now than formerly ${ }^{100}$. For the next few years the Judicial statistics continued to explain away the rise in the police figures as 'statistical', diplomatically discounting the police figures of rising crime by suggesting that some of the growth was caused by the increased «numbers and efficiency of the police » leading to more crime being discovered $^{101}$.

The 1925 commentary anticipated history repeating itself when it predicted that six years after the Boer War «the tide turned » for crime and that this was now the sixth year after the end of the Great War. Perhaps the Home Office was indicating to the police that six years of rising crime was quite enough. It called for an effort to be made to return to the ante-bellum level of crime, which was where the Home Office wished to be; «first, to securing a speedy return to the best standard recorded, and then to improving even upon that standard ${ }^{102}$. When the figures did not fall after six years, the Judicial statistics still denied that there was any "permanent tendency of serious crime» to rise $^{103}$.

In their Report for 1927-28, the Inspectors of Constabulary were optimistic, and predicted that the recent small increase in the size of the police establishment was "the trickle before a flood " ${ }^{104}$. The following year they promised «the demands for more men are likely to be heavy in the next few years ${ }^{105}$. They had sound reason for their optimism. The Judicial statistics, 1928, showed that the Home Office had finally given way after a decade of unrelenting police pressure. The Home Office grudgingly conceded at last that the police figures were «the best available guide to the volume of serious crime» ${ }^{106}$. In «the very long term» the Home Office still

\footnotetext{
Ibid. (p. 11).

98 Royal commission on police powers and procedures, (1929, QQ. 1126, 1123).

99 Judicial statistics, P.P. (1926 [Cmd. 2602], XXIX.437, p. 2).

${ }_{100}$ Judicial statistics, P.P. (1924-5 [Cmd. 2385], XXVIII.63, p.5).

101 Judicial statistics, P.P. (1927 [Cmd. 2811], XXV.201, p. 2).

102 Ibid. (p. 2).

103 Judicial statistics, P.P. (1928-9 [Cmd. 3301], XXI.683, p. v).

104 Inspectors of constabulary, P.P. (1928-9 (50), IX.43, p. 5).

105 Inspectors of constabulary, P.P. (1929-30 (69), XVII.1, p. 4).

106 Judicial statistics, P.P. (1929-30 [Cmd. 3581], XXX.395, pp. xvi-xvii, li).
} 
maintained crime was not increasing in relation to population and that it was still the pre-war pattern of crime statistics which was «normal». The 1928 edition, which was published in 1930 included an uniquely lengthy survey of patterns of crime since 1857 which it used to make a final defence of progressivism, and social reform policies as the most effective way to deal with crime. It restated its policy that the spread of education must have reduced crime rather than increased it, and that general improvements in family standards and less drunkenness, «ought» to lead to «a diminution in juvenile crime and petty offences... in years to come ${ }^{107}$.

1930 was a watershed in criminal policy when it was officially accepted that crime figures would continue to rise. In the four years 1929-33 the amount of indictable crime recorded by the Metropolitan Police, who were directly under Home Office control, quintupled from 17,664 to 83,668 so that the force now admitted to approximately one third of crime in England and Wales being committed within its boundaries. Significantly, the strength of the Met was also about one third of the total national police force ${ }^{108}$. It appears that the Metropolitan Police, and other forces, used the general increase in the statistics to reallocate their 'crime coefficients' amongst themselves. The aim may have been to produce a reasonable correspondence between the amount of crime reported, and the size of the police force, so that a national standard could viably be produced to include in any future Geddesstyle formula for assessing police numbers. This would explain why crime rose so little in Liverpool in the inter-war period when previously it had risen so rapidly. Dunning, had already so massively raised the City's 'co-efficient of crime' above the amount of crime, per officer, of other forces, that the City had to wait for the other forces to catch up.

\section{VIII.}

Although, so far, no major study has been made of local police statistics in this period, there is evidence that the statistics were being closely coordinated by the police establishment at the local and national level and so were doing more than merely following the apparantly random «fluctuations with an upward tendency» that characterized the statistics of individual forces ${ }^{109}$. McClintock and Avison examined trends in crime-rates for a number of different geographical groupings of forces, partly to forecast crime levels following a projected reorganization of police boundaries. They found taking «The incidence of crime and the increase in crime in each of the proposed new police areas.... it is found that for the years, 1955-65, there have been considerable variations in crime rates from one area to another ${ }^{110}$. Howe-

107 The idea that education ought to reduce crime had been under challenge since at least the $1830 \mathrm{~s}$, Radzinowicz, Hood (1990, pp. 54 ff).

108 Lord Trenchard, the Commissioner of the Metropolitan Police claimed most of this rise was due to the abolition of the 'Suspected Stolen Book'; Commissioner of the police of the metropolis, P.P. (1932-3 [Cmd. 4294], XV.319, p. 16).

109 Sir Llewelyn Atcherley, Inspectors of constabulary, P.P. (1930-1 (40), XVI.813, p 11). The picture was immensely complex as Hermann Mannheim showed in his study of crime in the inter-war period; Mannheim (1940). A full study of Chief Constable's annual reports, and local archive material would greatly illuminate the period.

110

Ibid. (p. 89). 
ver, when they examined the existing police conference regions they found a distinct pattern; « the national upward trend in crime from 1955 onwards has been reflected in the trends in each police conference region. Variations between regions are not great ${ }^{111}$. In other words, although the statistics of the individual police forces that comprised each of the nine police conference districts appeared to be showing no clear trend, when they were combined together at police conference level (but not when combined together in other groupings such as the proposed new police authority areas) they showed a close correspondence to the national trend. This suggests that the conference area was the basic statistical unit. Moreover, it appears at that level that senior police officers had a relatively free hand since at that level, in A.L. Dixon's opinion, their proceedings were nothing to do with the Home Office ${ }^{112}$.

Other evidence suggests the statistics were coordinated on a national scale with such precision that they could be raised or lowered by the number of serving officers. This appears to be the case when, at the end of the 1940s, the crime figures suddenly stopped rising and began to fluctuate up and down. In 1949, Ronald Howe, the head of the Metropolitan Police C.I.D. hinted that a turning point had been reached. That year the figures fell enormously, providing a convenient breathing-space for detectives. He wrote, «Now, and especially where I work in the largest City of the world with all the problems that follow a great war, our detectives, as they move from case to case, sigh for the time for detailed investigation... now I feel that, after a long period of overwork since the war, we are gradually getting back to proper investigation, which will lead to proper results ${ }^{113}$. The explanation commonly advanced was that the late 1940s and early 1950s was « a period of social adjustment following the aftermath of the war and the consolidation of the welfare state... At the time these oscillations were taken too indicate that the upward curve in crime had reached its peak and would shortly fall and become stabilized at a pre-war level ${ }^{114}$. However, others were more suspicious. In 1977, Sir Leon Radzinowicz, the leading British criminologist, speculated without providing his readers with any further evidence; «Could the short-lived respite enjoyed in the nineteen-fifties be attributed to a sudden police go-slow?» ${ }^{115}$.

It appears Radzinowicz's speculation was well-informed. The late 1940s and early 1950 s were a time of intense competition between the political parties. At the end of the war, the police claimed that the combined effect of the Depression and of the War had led to their pay and status being eroded. Officers called for another Desborough-type pay award or a new police charter. In 1945 the crime figures rose sharply and began to push crime, which had not «immediately» pressed itself «upon the government's attention», up the political agenda ${ }^{116}$. In September 1946 the police received a pay rise on condition that pay would remain frozen for three years during which there would be « a comprehensive review of police conditions of service $"{ }^{117}$. Grievances built up. By 1948, «there was mounting discontent in the

111 McClintock, Avison (1968, p. 88).

112 Select committee on the amalgamation of police forces, (1931-2, p. 186).

113 Howe (1949, p. v).

114 McClintock, Avison (1968, p. 19).

115 Radzinowicz (1977, p. 6).

116 Morris (1989, p. 74).

117 Judge (1994, pp. 100-101). 
police service, criticism in Parliament, and a serious problem of inadequate recruitment $\gg{ }^{118}$. Detective departments, in particular, were over-loaded and needed either more men, or a reduction in crime. The Police Federation pressed for an independent pay review.

The Government responded by passing a series of acts bringing some institutional change to the administration of criminal justice. Crime was clearly back on the agenda and the 1948 Criminal Justice Act provided a few extra long-term prison slots and the opportunity for courts to award short, sharp shocks for juveniles. Nonetheless, the 1948 statistics shot up to reach a record 522,684 crimes. Never before had the number of recorded crimes passed the symbolic figure of 500,000. In May, the Government agreed to set up the Oaksey Committee on Police pay and recruitment ${ }^{119}$. The following year recorded crimes fell back by an astonishing 62,815 to 459,869 . Since 1916 , the crime rate had only previously fallen twice, each time by about 6,000, in 1927 and 1946 . The 1949 fall was, therefore, 1,000 per cent greater than any other ever recorded. In this light, it was perhaps significant that the total actual strength of the police in England and Wales at the end of 1949 was 61,166 or 97.37 per cent of the 62,815 total fall in crime ${ }^{120}$. Since they were forbidden to take industrial action, it appears the police gave the Government a most impressive display of power and solidarity by reducing the crime figures by almost one crime for every serving officer.

Nonetheless, the Oaksey Committee, which reported in 1949 during a pay freeze ${ }^{121}$, recommended only a 15 per cent rise whereas the police had asked for between 33 per cent and 54 per cent. The police remained dissatisfied and recruitment remained a major problem. In 1951 the police again came back for a pay rise, and the crime figure for 1951 went back up massively by about 14 per cent to 524,506 , a rise of 63,071 . The number of serving police officers at the end of 1951 had by now risen to 63,116 , or only 35 officers more than the rise in crime. Again the police were granted a pay review. In August 1951 constables were given another 20 per cent on top of the Oaksey award ${ }^{122}$. The crime figure for 1952 fell back slightly to 513,559 . Early in 1952, Chief Constables and all grades above superintendent were in their turn awarded a back-dated flat rate increment of $£ 150^{123}$. The crime figure for 1953 fell back about 7 per cent to 472,989 . In 1954 a further 9 per cent was awarded to the police. The crime figure again fell back over 8 per cent to 434,327 and rose less than 4,000 the following year.

"1954 saw the end of the temporary recession in crime» ${ }^{124}$. In the 1955 general election, the Conservatives gained the clear electoral ascendency over Labour. Between then and 1960 the police submitted three further claims for pay rises, but there was no longer the same political pressure to meet police demands and each time no agreement was reached and the claims had to go to arbitration ${ }^{125}$. Over the next few

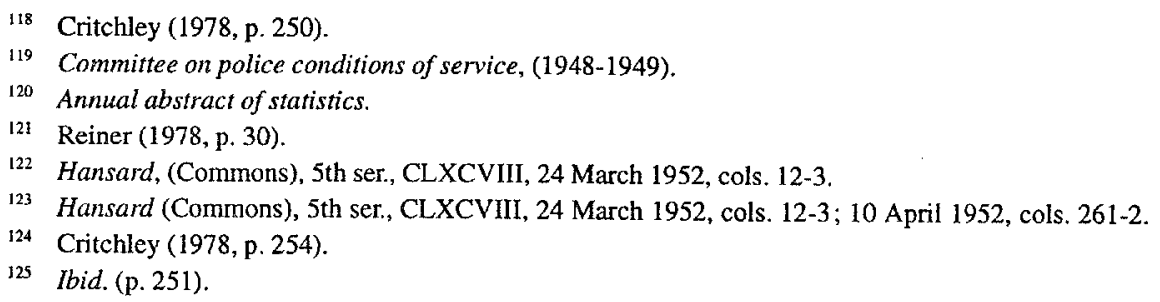


years the crime statistics rose at a massive rate. In 1956 they went up nearly 10 per cent to 480,000 . In 1957 they rose nearly 14 per cent to 546,000 , after that they continued to rise at around 10 per cent per annum until the early 1960s and then at a slightly lower rate after that.

Given the political context at the time, and also that the crime statistics had never before fallen by such an order of magnitude, direct control of the statistics provides a far more likely explanation than simple coincidence, for why the number of crimes should have risen and fallen by almost exactly the number of serving officers. This evidence also suggests that it may have been possible, in some way, for a national total figure for crime to have been set in advance and for this then to have been divided between the nine conference areas for parcelling out to individual forces. If further research were to confirm that there was central control, it would go a long way towards explaining how the criminal statistics maintained such an astonishingly uniform rate of increase for nearly eighty years (figure 1) despite the many social, demographic, and economic changes that transformed society during that period.

IX.

In the 1960s, J.J. Tobias, a British historian of crime, expressed his grave doubts about the utility of the British judicial statistics which, he said, «have little to tell us about crime and criminals ${ }^{126}$. The only factor he found that consistently affected the statistics was a change in the chief constable for a particular district ${ }^{127}$. This paper largely endorses Tobias' findings but extends his conclusions. The reason, it suggests, that a change of chief constable affected the statistics was that both the quantitative and qualitative recording of crime was largely pre-determined by supply-side factors such as politics, budgets, and pay, and not by demand, that is to say the amount and type of crime originally reported to the police. Of course, the quantity and quality of crimes that were reported by the public to the police were beyond their control, however, how they were recorded and processed was a matter of policy and that policy was set by the chief constable. Therefore, the immense value of the statistics to the historian is not that they allow conclusions to be drawn about the quality or quantity of crime in the real world, but rather that an historically contextualized reading of the statistics greatly assists in the reconstruction of the supply-side quotas, policies, priorities and politics that underlay criminal justice.

From this it follows that, in most cases, it is methodologically invalid to use the judicial statistics as an indicator of the effectiveness of other social programmes. Nonetheless, as the police establishment continued to widen the base of its statistics after the First World War, it convinced politicians and the public that crime was really increasing by leaps and bounds and this, in turn, helped misrepresent the outcome of welfare and educational policies as at best ineffective sentimentality and at worst a foolish and profligate transfer of resources to the lowest moral strata of society. Terence Morris, a British criminologist, has described how «increasingly after $1945 . .$. popular sentiment was often prone to suggesting that the increased pro-

126 Tobias (1972, p. 25).

127 Ibid. 
vision of welfare resulted in sapping of the moral fibre of the nation... it was but a short step to including increased criminality, and especially juvenile criminality, as one of the perhaps unintended but nevertheless inevitable consequences ${ }^{128}$. The long-term result of this was that by the 1990 s crime had replaced poverty and the welfare of the nation as a major political problem in Britain.

The Desborough award had transformed the politics of crime for the rest of the twentieth century. By triggering rising crime statistics, it moved crime control back onto the political agenda as a major competitor for precious resources against social services. Yet, the decision, whether or not crime control merited increased resources, was not made on the basis of statistics that allowed any meaningful assessment to be made of the extent of crime or of the effectiveness of increased police resources in controlling it. In the early 1930s the ominous direction criminal justice was taking had already been noted by Dan Griffiths, a member of the Departmental Committee on the Persistent Offender. He warned that crime

has been raised to the status of an institution and has become a profession and a kind of vested interest to a host of respectable people who make a living out of criminal law administration... It is not natural to expect people who live on crime, rather than by crime, to be willing to jeopardise the source of their own livelihood $^{129}$.

\author{
Howard Taylor \\ Department of History \\ University of Nottingham \\ University Park \\ NG7 2RD, U.K. \\ (howard.taylor@nottingham.ac.uk)
}

\title{
REFERENCES
}

Anderson, D.M., Killingray, D., Policing and Decolonisation: Politics Nationalism and the Police, 1917-1965, Manchester, Manchester University Press, 1992.

Atcherley, Maj.-Gen. L.W., Brook, Lieut. Col. F., Criminal Investigation and Detection, Wakefield, County Chief Constable's Office, 1932.

Bailey, V., Delinquency and Citizenship: Reclaiming the Young Offender, 1914-1948, Oxford, Oxford University Press, 1987.

Bottomley, K., Coleman, C., Understanding Crime Rates: Police and Public Roles in the Production of Official Statistics, Famborough, Gower, 1981.

Committee on the Police Service of England Wales and Scotland, minutes of evidence, P.P. (1920 [Cmd. 874], XXII.573).

Committee on Police Conditions of Service, P.P. (1948-9 [Cmd. 7674, 7831], XIX.251, 379).

Committee on National Expenditure, second interim report, P.P. (1922 [Cmd. 1582], IX.173).

Critchley, T.A., A History of Police in England and Wales, rev. ed., London, Constable, 1978.

Departmental Committee on the Duties of Women Police, minutes of evidence, P.P. (1921

[Cmd. 1133], XV1.73).

\footnotetext{
128 Morris (1989, p. 37).

129 Reservation by Mr Dan Griffiths, Departmental committee on the persistent offender (1931-2, p. 69).
} 
Departmental Committee on the Persistent Offender, P.P. (1931-2 [Cmd. 4090], XII.553).

Dixon, A.L. Some aspects of co-operation within the police service, Annual Report of the Chief Constable's Association (Cities and Boroughs of England and Wales), 1936, pp. 51-60.

Emsley, C., The English Police : a Political and Social History, Hemel Hempstead, Harvester Wheatsheaf, 1991.

Garland, D., Punishment and Welfare : a History of Penal Strategies, Farnborough, Gower, 1985.

Hobbes, T. Leviathan, or the Matter, Forme and Power of a Common-wealth Ecclesiastical and Civil, London, Everyman's Library, 1950.

Howe, R.M., (ed.), Criminal Investigation : a Practical Textbook for Magistrates etc., London, Sweet and Maxwell, 1949.

Judge, A., The First Fifty Years: the Story of the Police Federation, London, Police Federation, 1968.

Judge, A., The Force of Persuasion : the Story of the Police Federation, Surbiton, The Police Federation, 1994.

Lopian, B.J., Police and Punishment 1918-1929; Metropolitan Experiences, Perceptions and Policies, PhD Dissertation, University of Cambridge, 1986.

MacGregor, Det. Sgt. A.M., Criminal statistics, Police Journal, 1953, 26, p. 35-44.

Mannheim, H. Social Aspects of Crime in England between the Wars, London, Allen and Unwin, 1940.

Martin, J.P., Wilson, G., The Police : a Study in Manpower, London, Heinemann, 1969.

McClintock, F.H., Avison, N.H., Crime in England and Wales, London, Heinemann, 1968.

Morgan, J., Conflict and Order: Labour Disputes in England and Wales 1900-1939, Oxford, Oxford University Press, 1987.

Morris, T., Crime and Criminal Justice since 1945, Oxford, Basil Blackwell, 1989.

Moylan, J.F., Scotland Yard and the Metropolitan Police, London, G.P. Putnam, 1929.

Nott-Bower, Sir W., Fifty-two Years a Policeman, London, Edward Arnold, 1926.

Nozick, R., Anarchy, State and Utopia, Oxford, Basil Blackwell, 1980.

Papers submitted to the education committee by E. Chadwick, PP. (1862, XLIII).

Radzinowicz, L., English Criminal Statistics; a Critical Analysis, in Radzinowicz, L., Turner,

J.W.C. (eds.), The Modern Approach to Criminal Law, English Studies in Criminal

Science, vol. IV, London, Macmillan, 1945.

Radzinowicz, Sir L., The Growth of Crime, London, Hamish Hamilton, 1977.

Radzinowicz, L., Hood, R., The Emergence of Penal Policy in Victorian and Edwardian England, Oxford, Clarendon, 1990.

Reiner, R., The Blue Coated Worker, Cambridge, Cambridge University Press, 1978.

Reynolds, G.W., Judge, A., The Night the Police went on Strike, London, Weidenfeld and Nicolson, 1968.

Royal commission on police powers and procedures, minutes of evidence, H.M.S.O., 1929.

Scotson, T., An Examination of Crime and Criminal Justice in the Literary Utopias of 1880 1914, PhD Thesis, University of Leicester, 1994.

Searle, G.R., The Quest for National Efficiency: a Study in British Politics and Political Thought, 1899-1914, Oxford, Oxford University Press, 1971.

Select committee on the amalgamation of police forces, P.P. (1931-2 (106), V.123).

Spencer, H., Social Statics: or the Conditions Essential to Human Happiness Specified, and the First of them Developed, London, John Chapman, 1851.

Stevenson, S.J., Reflections on the Attempt to Rationalize the Distribution of Police in England and Wales, 1942-1974, Twentieth Century British History, 1995, 6, 1, p. 56-77. 
Taylor, H., The Politics of Crime in Interwar England and Wales: with Particular Reference to some Discontinuities with Nineteenth Century Criminal Justice Policy, PhD thesis, University of Nottingham, 1997.

Taylor, H., Rationing crime: A Political Explanation of the Constancy of Criminal Statistics of England and Wales in the Victorian Period and Later, Economic History Review, 1998, LI, forthcoming.

Thomson, B., The Story of Scotland Yard, London, Grayson \& Grayson, 1935.

Tobias, J.J., Crime and Industrial Society in the Nineteenth Century, London, Penguin, 1972.

Troup, Sir E., The Home Office, London, G.P. Putnam Sons (Whitehall Series), 1925.

Webster, C., Healthy or Hungry Thirties?, History Workshop Journal, 1982, 13, p. 110-29.

Weinberger, B., Keeping the Peace? Policing Strikes in Britain 1906-26, Oxford, Berg, 1991.

Wiener, M., Reconstructing the Criminal: Culture, Law and Policy in England, 1830-1914, Cambridge, Cambridge University Press, 1990.

Young, M. An Inside Job: Policing and Police Culture in Britain, Oxford, Clarendon Press, 1991. 